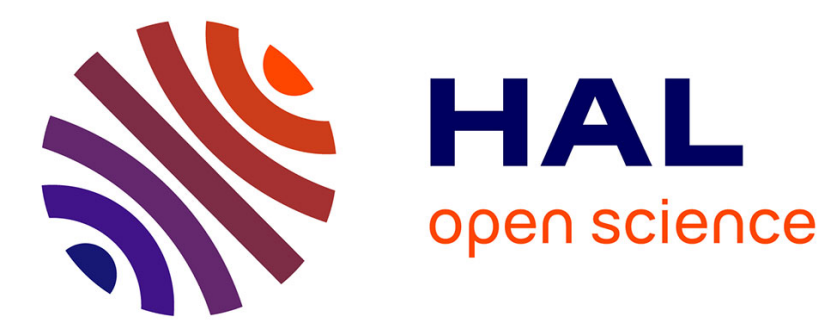

\title{
Innovation in services: A review of the debate and a research agenda
}

\author{
Faïz Gallouj, Maria Savona
}

\section{To cite this version:}

Faïz Gallouj, Maria Savona. Innovation in services: A review of the debate and a research agenda. [Research Report] University Lille 1, Clersé. 2009. hal-01111796

\section{HAL Id: hal-01111796 \\ https://hal.science/hal-01111796}

Submitted on 31 Jan 2015

HAL is a multi-disciplinary open access archive for the deposit and dissemination of scientific research documents, whether they are published or not. The documents may come from teaching and research institutions in France or abroad, or from public or private research centers.
L'archive ouverte pluridisciplinaire HAL, est destinée au dépôt et à la diffusion de documents scientifiques de niveau recherche, publiés ou non, émanant des établissements d'enseignement et de recherche français ou étrangers, des laboratoires publics ou privés. 


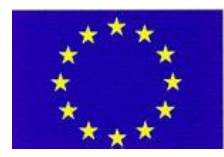

The European Commission
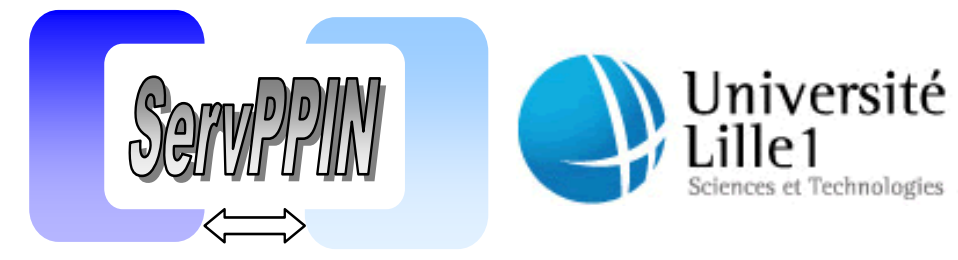

ServPPIN: The Contribution of Public and Private Services to European Growth and Welfare, and the Role of Public-Private Innovation Networks

WP 2: Public and private service innovation and impact assessment

Deliverable 2.1 -A1.1a July 2009

Innovation in services:

A review of the debate and a research agenda

Faïz Gallouj* and Maria Savona**

* University of Lille 1 (France)

** University of Lille 1 (France) and SPRU, University of Brighton (GB) 


\begin{abstract}
The paper reviews the debate on innovation in services which has flourished over the last 20 years and suggests a research agenda for the services innovation literature. We discuss whether, and the extent to which, the ill-definition and mis-measurement of service output have influenced the conceptualization and analysis of innovation in services. We propose a reclassification of the literature according to whether it has been mainly assimilated or differentiated with respect to the traditional conceptualization of innovation in the manufacturing sector. We also review the integrative (or synthesizing) contributions, and suggest a taxonomy for the modes of innovation in services, based on the Lancasterian characteristics-based approach to product definition. We conclude with a summary of the key arguments and a proposed agenda for the evolutionary theory to integrate the conceptualization of innovation in services.
\end{abstract}


Innovation in services:

A review of the debate and a research $\operatorname{agenda}^{1}$

Faïz Gallouj* and Maria Savona**

* University of Lille 1 (France)

** University of Lille 1 (France) and SPRU University of Brighton (GB)

\section{Introduction}

The theoretical, and always somewhat controversial, debate around the causes and consequences of the growth in services dates back to the 1930s, over time pitting optimistic advocates of the 'post-industrial era' (Fourastié 1949; Bell 1973; Browning and Singelmann 1978) against sceptical 'neo-industrialists' (Baumol 1967; Fuchs 1968, Cohen and Zysman 1987; Gershuny 1978) ${ }^{2}$. Recently this debate has lost some of its liveliness but has not reached any ground of agreement. Now the role of technical change and innovation is entering the debate, potentially providing support for both sides: either the service sectors are laggard innovators and - at best - passive adopters of technology from elsewhere, or they represent the core engine of the new knowledge based economy.

We argue that this ambiguity is due to the stickiness of the concepts employed to define, measure and analyze services, which characterized the old debate, the controversies they encompassed and, more generally, the inertia of the analytical and conceptual apparatus that is applied to define the service output. The materiality-bias that characterizes the distinction between manufactured goods and services has led to the mis-measurement of

\footnotetext{
${ }^{1}$ Published in Journal of Evolutionary Economics (innovation in services : a review of the debate and perspectives for a research agenda, The Journal of Evolutionary Economics, Volume 19, Issue 2 (2009), 149172).

${ }^{2}$ For a review of the two opposite approaches of post- and neo-industrialists, see the extensive review provided by Delaunay and Gadrey (1992). See also Petit (1986) and Schettkat and Yocarini (2006).
} 
economic performance in services. Similarly, we lack a careful conceptualization of innovation in services, which most likely also leads to an underestimation of innovation in this area.

This paper reconsiders the dominant views in the old debate on the determinants and economic impact of the growth of services, and some of the key issues related to the definition and measurement of service output (Section 2). It identifies whether, and the extent to which, such views have influenced the conceptualization and analysis of innovation in services. We propose a reclassification of the literature according to whether

it has been mainly assimilated or differentiated with respect to the more traditional consideration of innovation in the manufacturing sector (Section 3). We also review the integrative (or synthesizing) contributions, and suggest a taxonomy for the modes of innovation in services, based on the Lancasterian characteristics-based approach to product definition (Section 4). Section 5 concludes with a summary of the key arguments and a proposed agenda for evolutionary theory to integrate the conceptualization of innovation in services.

\section{The evolving theory of value and the materiality bias: the ill-definition and mis- measurement of services output}

This section reviews some of the most influential work on services, some of which is rooted in the history of economic thought and reflects the evolving theory of value. We would argue that the conceptualization of innovation in services is dominated by these views, which also dominate the economic and political discourses, nurtured by sceptical neo-industrial scholars, mainly concerned with the productivity slowdown argument. We briefly review the main issues related to the mis-measurement of service economic performance, which most likely stem from the ill-definition of service output. 


\subsection{Productive and non-productive activities - from the classical tradition to Baumol's cost-disease}

The first and by far the most influential aspect of growth in services, relates to the specificity of the service production process and the productivity gap between services and manufacturing activities. This specificity has its roots in the earliest speculations over the role of services, the 'classical tradition', and reached maturity with Baumol's and Fuchs's attempts to interpret the causes of the productivity slowdown that occurred in the advanced countries, relative to the early post-World War II years (1948-1965) (Baumol and Bowen 1966; Baumol 1967; Fuchs 1968, 1977; Baumol et al.,1989).

A detailed review of services in the history of economic thought by Delaunay and Gadrey (1992), addresses Adam Smith's (and the Smithian) lines of argument against the rise of services, in the context of the classical theory of value, mostly opposing the mercantilist view of the determinants of the wealth of nations. Delaunay and Gadrey point out that Smith's The Wealth of Nations includes at least two criteria against which the 'threat' of service activities growth should be considered. Both of these refer to the concept of productive vis-à-vis non-productive labor.

Interestingly, the first of these criteria is in line with the mercantilist approach to labor as an income generating activity and, therefore, subject to taxes that add to the fiscal treasury. In this respect, services do produce value insofar as the labor employed in service activities produces income, regardless of the physical/immaterial type of output. Unproductive labor, by contrast, "adds to the value of nothing" (Smith 1960 [1776], Book II, opening para. of Ch. III) - for instance, the menial servant as opposed to waged-labor in manufacturing industry. In other words, productive labor generates profits on the capital investments to which it is applied. The bottom line is whether this labor belongs to the commercial or the industrial sphere. $^{3}$

\footnotetext{
${ }^{3}$ It is beyond the scope of this paper to provide an overview of the classical tradition. However, it is interesting to consider here that Marx's classification of service activities was mainly based on the social and economic relationships underlying the provision of services, rather than the physical manifestation of such provision. Interestingly, he considers transport services to be part of industrial production, and therefore part
} 
The second and, in some respects, more famous criterion contradicts the first. This refers to the ability of labor to substantiate itself in a physical output and, therefore, to contribute to capital accumulation. This criterion by definition excludes services from the sphere of productive labor, regardless of the ability to generate income. The following quote is selfexplanatory: "Unproductive labour does not fix or realize itself in any particular subject or vendible commodity. His services generally perish in the very instant of their performance, and seldom leave any trace of value behind them, for which an equal quantity of services could afterwards be procured" (Smith 1960[1776], Book II, first para. of Ch. III). In the second paragraph of Chapter III, Smith puts the same emphasis (and expresses the same concern) on the process of the erosion of capital accumulation due to the increasing presence of "unproductive hands", despite some of them being "honourable, useful, necessary" (protection, security and defence).

Clark (1940), Fisher (1935) and Fourastié (1949), pioneers of the three-sector split model, provide definitions of service activities based on the different scales of production and the lower average growth of productivity in services compared to primary and manufacturing activities. These contributions assume a lower rate of productivity growth in services, rather than considering evidence of it as the object of their analyses.

The second generation debate on the nature and consequences of services growth developed in the 1960s. The concept of a 'cost disease' has remained implacably associated with the productivity performance of service industries since Baumol and Bowen (1966) first referred to the "cost disease of a string-quartet performance". The concept was extended by Baumol in a very influential 1967 paper (Baumol 1967), and in further contributions by Baumol and colleagues (Baumol et al 1985, 1989; Baumol 2001, 2002).

of the material sphere, as well as a source of surplus value. Unlike transport, trade and banking are categorized as belonging to the sphere of "commercial and financial capital"; they produce neither value nor surplus value, but only add to the profits. More specifically, these activities are not labelled unproductive because of their immateriality, a criterion that many scholars applied at the time; instead, they were seen as part of more a complex speculation as far as their role within the social reproduction of capital was concerned (Delaunay and Gadrey 1992). 
Baumol assumes that the demand for services and goods, measured in constant prices, does not depend on the level of income and that, at the aggregate level, the share of services in total output is constant over time and across countries. Yet, as the increase in (labor) productivity levels is lower in services than in manufacturing and combines with low productivity growth over time, the high-income countries will experience higher shares of employment in services. The cost disease phenomenon consists of the fact that wages in services increase in line with average growth rates of wages in the rest of the economy, leading to overall increases in the nominal shares of output in services. The presence of a cost disease shows that the changing structure of employment in services is due to the lack of productivity gains in services rather than changing patterns of demand. The difficulty of achieving productivity gains in line with the rest of the economy, in turn, is a consequence of 'technological stagnancy' in services as compared to manufacturing sectors.

In the same vein, the neo-industrialists were concerned with the productivity slowdown issue. In a study revealingly entitled Manufacturing Matters, Cohen and Zysman (1987) view services as 'peripheral' activities crowding out manufacturing industry, which is regarded by them as the only engine of economic growth. The classical view of services as unproductive also lies at the heart of the study by Bacon and Eltis (1978) published in Too Few Producers. The service sector is also blamed for the economic crisis of the early 1970s (Aglietta and Brender 1984; Lorenzi et al. 1980), and the image of services as a 'pathology' flourishes in the economic literature (see in particular Attali 1981).

Some of the more recent critiques of Baumol's assumption of the 'constancy of services' hypothesis have shown empirically that up to the mid-1970s this would have held. Further, as with Ten Raa and Schettkat (2001), Appelbaum and Schettkat (2001) argue that the main assumption behind cost disease is in turn linked to the assumption of a zero price elasticity of demand for services, or, rather, to a perfect compensation mechanism between a negative price elasticity and a positive income elasticity of demand for services, which is not often (practically never) the case. The Baumol-Fuchs idea of a 'structural burden' in terms of aggregate labor productivity growth linked to the structural change favoring tertiarization of employment in advanced economies, is being challenged empirically more and more 
frequently (Kutscher and Mark, 1983; Peneder, 2001; Peneder et al. 2003; Savona 2004; Savona and Lorentz 2005; Cainelli et al. 2006; Kox and Rubalcaba 2007).

\subsection{The definition of service output and the measurement issues}

The above can be regarded as the general context for the conceptualization and assessment of innovation in services from its first steps in the 1990s, reviewed in Sections 3 and 4 below. As well as this general context, there is the specific, concrete analytical problem of the definition of services output, which also substantially contributes to the persistent bias in terms of productivity assessment. The ill-defined nature of the output of service activities is an issue which has been left pretty much unresolved, except for those few attempts that have devoted analytical efforts to providing a new definition of product based on Lancasterian production theory (Gallouj and Weinstein 1997; and, more recently, Djellal and Gallouj 2008a; Windrum and Garcia-Goni 2008). These are reviewed in Section 4 in the context of innovation theory.

The most important analytical problem in relation to services is the fuzzy nature of their product, due to the immateriality of the outcome of production and delivery. Service output is not embodied in anything that is physically quantifiable. It is a process, a sequence of operations, a formula, a protocol, a problem solution. The main consequences of issues related to output definition are associated with measurement. Measurement biases in relation to services are responsible of the great majority of the underestimations of innovation and economic performance. These problems were highlighted in the early 1990s by Griliches. His contribution, Output Measurement in the Service Sector (Griliches 1992) can still be considered the most exhaustive account of the measurement problems related to service activities (for an updated survey see Djellal and Gallouj 2008b).

Griliches argues that most of the problems linked to output measurement in the service sector are related to the following:

(i) the nature/content of the transaction (e.g. in the service provided by a physician is it the procedure itself, the consultation, or the results of the cure?); 
(ii) the nature of the user involvement in the definition of the service output, which makes it more difficult to standardize and consequently to price;

(iii) the quality change that is possibly more difficult to detect in services and to account for in price structures.

One approach to tackling the issue of the mere definition of service output in national statistics is from the perspective of the 'transaction', as opposed to the physical volume of goods and materials in manufacturing, which in turn is weighted by price (somehow). Yet, the transaction approach does not disentangle the problems related to the conceptual issues in (ii) and (iii) above. In particular, the notion of a transaction changes according to the degree of customer involvement; therefore, the delivery of a service might depend on the presence and co-operation of the user, which contributes to the completion of the transaction. Services are in fact consumed as they are being produced, and this involves some degree of customer participation. This characteristic has several theoretical consequences not only for the definition of the product, but also for the definition and the organization of service innovation. For example, it would seem to undermine a linear conception of innovation, as it is consistent with an interactive model, such as that advanced by Kline and Rosenberg (1986) (see Sundbo 1998; Sundbo and Gallouj, 1999).

Furthermore, tackling the issue of quality change requires the choice of an appropriate price index. Recently, this has led, particularly in the United States, to the use of hedonic pricing techniques, which, in adjusting price indexes, take quality into account (Griliches 1971, 1992; Moulton 1991; see also Moulton 2001 for a recent review). This methodology might become a sound way to overcome the problem of productivity lags in services, as the use of hedonic prices will increase both output and productivity figures, especially in newly emerged services which have experienced a great pace of technological change. Incidentally, the use of hedonic pricing techniques might explain a great deal of the productivity gap that exists between European and American measurements of their respective service sectors. 
What is the role of the measurement issues nowadays? Intangible elements and interactivity are becoming increasingly important in manufacturing. A sounder conceptualization of (service) product definition - which takes due account of such specificities - is argued here to be able to add to the theory of innovation, and to reconcile the two basic features of modern economies, services and innovation. A substantial step in this direction was achieved by Djellal and Gallouj (2008a).

\section{A framework to conceptualize innovation in services: assimilation and differentiation approaches}

We have shown that the dominance of the materiality bias -- and unresolved issues related to the definition of service output - have all contributed to the mis-measurement of the performance (productivity and value added) of service activities. The very same issues have affected the conceptualization of innovation in services and the under-estimation of their innovative performance. In previous works (Gallouj 1994, 1998, see also Gallouj and Weinstein 1997), one of the authors of this paper proposed a framework (which has been widely adopted - see, for instance, Miles 2002, 2005, Tether, 2005, Howells, 2006) to reclassify the literature on innovation in services. This literature can be reclassified according to three main approaches.

1. A technologist or assimilation approach that equates or reduces innovation in services to the adoption and use of technology (for instance, information and communication technologies - ICTs). Contributions in line with this approach attempt to assimilate services within the consolidated framework used for manufacturing sectors and manufactured products.

2. A service-oriented or differentiation approach that seeks to identify any possible particularities in the nature and organization of innovation in services. This stream of literature attempts to develop a specific framework for service innovation, while attempting to highlight all the specificities in service product and production processes. 
3. An integrative or synthesizing approach, which, taking as a starting point the trend towards convergence between manufactured goods and services, attempts to develop a common conceptual framework, able to account for an enlarged view of innovation which is applicable to any tangible or intangible product. Unlike the technologist and serviceoriented approaches, this last view, within which we propose a new taxonomy of innovation in services (Section 4), is based on a new definition of product.

These three approaches fit into what might be considered the natural life cycle of theoretical concerns. The technologist approach is in a phase of relative decline: the pioneers of research on innovation in services naturally adopted a technologist 'gaze' that had its roots in a manufacturing-led economy. The service-oriented approach is in its mature phase: the following generation of researchers attempted to highlight the specificities of services, possibly even overplaying them. The integrative approach is in the emerging and expanding phase: attempts are being made to embrace, within a unique framework, both goods and services. However, a proper integration should by no means overlook the specificity of services or the concern for the purely technological aspects of innovation in services.

Whether falling within the technologist, service-oriented or integrative approach, contributions can be (i) theoretical, (ii) typological or (iii) empirical. These last are mainly concerned with (empirically based) impact analyses.

We start by reviewing the main contributions within the technologist (Section 3.1) and the service-oriented (Section 3.2) approaches. We then focus on the integrative approach (Section 4), and propose a characteristics-based taxonomy of innovation.

\subsection{The Technologist (Assimilation) Approach}

The literature that considers innovation in general - and innovation in services in particular - as strictly represented by technology-related changes of products, is by far the oldest and the most dominant in terms of the number of contributions. This, to some extent, 
has influenced the overestimation of the technological dimension or, more precisely, has led to the underestimation of other,non-technological,aspects of innovation in services.

The main argument for this approach is that the service industries are becoming increasingly technology- and capital-intensive. Innovation in services is often driven primarily by the adoption of technologies and capital equipment, with non-technological innovations being marginal.

The technological dimension of innovation in services emerged relatively recently with the diffusion of ICTs, mostly in the business services. The term Knowledge Intensive Business Services (KIBS) is now widespread, accompanied by a burgeoning number of contributions emphasizing the role of ICTs in services and in the New Economy (OECD 2000a, 2000b, 2000c, 2001). Not all of these contributions are enthusiastic about the new economy(see for instance Daveri 2002). Nevertheless, the use of ICTs has been steadily increasing in service industries traditionally described as non-informational (e.g. cleaning, transport, hotels) (Djellal 2000, 2002), which are certainly not included in the glamorous New Economy rhetoric. Indeed, innovation in services is becoming an increasingly complex issue, in which the adoption of ICTs is just one of many possible facilitators. As Djellal and colleagues (2003) point out, the adoption of ICTs, in the great majority of the cases, is complemented by organizational engineering activities, which result in new firm organizational architectures. ${ }^{4}$ In other words, the distinction between ICT producers -i.e. the manufacturing sector - and ICT users - traditionally services, has become more and more blurred.

A number of technologist contributions follow Pavitt (1984) and extend his taxonomy to services. Few of these studies are empirically based, and most draw on large surveys, such as the European Community Innovation Survey (CIS). Within the theoretical contributions along this line, the most influential is undoubtedly the work by Barras.

\subsubsection{Barras's Reverse Product Cycle Model: A Theory of Innovation in Services?}

\footnotetext{
${ }^{4}$ See also Windrum et al. in this special issue.
} 
One of the seminal contributions on the nature of innovation related to firm characteristics, is that of Abernathy and Utterback $(1975,1978)$. The authors develop a dynamic model that links the competitive strategy of the firm, the stage of development of the production process (i.e. the industry life cycle - Kuznets 1957, 1966) and the pattern of innovation. In the early stages of the product life cycle, characterized by low standardization and high attention to market needs, firms tend to proceed via uncoordinated process development aimed at maximizing product quality. Over time, as the market matures, the main source of process development is the exploitation of technological opportunities rather than market needs, which brings about a strategy of product differentiation through segmental process development. Finally, as markets become saturated, firms adopt cost-minimizing strategies through a process of systemic development, aimed at standardizing their production. Abernathy and Utterback's dynamic model presents a trajectory of process development and innovative strategies within an industry life-cycle framework.

Barras $(1986,1990)$ adopted this framework to develop a dynamic model of innovation explicitly to account for the specificity of the production processes in service firms and industries. In his Reverse Product Cycle (RPC) Model, Barras argues that ICTs represent the "enabling technology" (Barras 1990, p. 215) created elsewhere and adopted by the service sectors, which accounts for their innovation potential. Three evolving stages are identified: incremental process innovation, radical process innovation and, finally, product innovation. Barras argues that the nature of the innovation introduced depends upon the different stages of ICT adoption, and the existence of a learning curve behind the adoption process. He also assumes that, in the case of financial services, a service innovation, in some respects, represents a more radical process innovation (Barras 1990, p. 226).

The first stage is characterized by a 'supplier dominated' condition, which allows the adoption of the enabling technology and the exploitation of technological opportunities. The adopting industry (services), therefore, develops an incremental process innovation aimed at increasing the efficiency of the production process (the last stage in Abernathy and Utterback's model). 
In the second stage, characterized by a higher point in the learning-by-doing curve, radical process innovations take place, aimed at improving the quality of the service provided, through a process of selective standardization.

The third stage is 'user dominated' in the sense that the expansion of technological opportunities allows the introduction of radical service innovation: "the more radical the service innovations become, the more reasonable it is to identify the resultant improvements in service delivery as new services" (Barras 1990, p. 226).

The RPC model is less focused on the traditional product life cycle and more on the alleged effects of the adoption of the technology. Further, as Gallouj (1998) puts it, the RPC model can be seen only as a consistent attempt to stylize the dynamics of the adoption and diffusion of ICTs in financial services, rather than a theory of innovation in services. The critical aspects raised by Gallouj are in fact related to the generalizability of the model. Some points remain to be clarified:

- $\quad$ Is the RPC model valid beyond ICT adoption?

- Is the RPC model valid beyond ICT adoption in sectors other than financial services?

- Is the RPC model valid for the service functions internal to the manufacturing sectors? (If so, then such a model might be generalized to the whole economy as a general model of adoption and diffusion of ICTs.)

The core of Gallouj's critique of Barras' model is, as mentioned above, related to its technological determinism and the tendency to undermine service specificity. In particular, Gallouj argues that taking into account only the technological characteristics of innovation might lead to an underestimation of the variety of non-technological innovation that takes place in services. Barras' focus on product and process innovation is therefore reductionist when viewed within a neo-Schumpeterian framework, and is potentially able to account for a much broader range of possible sources of innovation. If this point holds, Barras' attempt 
actually turns out to be "a neo-Schumpeterian synthesis of many studies on the impact of ICTs on services" (Gallouj and Weinstein 1997, p. 418).

The fact that Barras's model relies on some unresolved issues specifically related to the nature of service products and production processes, actually weakens its explanatory power. We should mention that the difference between product and process still presents a certain degree of ambiguity as far as services are concerned, due to the characteristics of intangibility and co-terminality between production and consumption of services. This makes it even more difficult to disentangle the nature of innovation in services, as the distinction between product and process innovations in services becomes less clear-cut.

\subsubsection{Taxonomies of Sectoral Technological Trajectories}

Drawing on a data set of more than 2,000 observations on 'significant innovations and innovating firms' in the UK across the period 1945-1980, mainly relating to the sectors using the innovation and the sources of knowledge for the innovation, Pavitt (1984), in a very influential paper, codifies the variety of innovations across firms (and sectors). He identifies five categories: 1) supplier dominated; 2) production intensive, among which (i) scale intensive and (ii) specialized suppliers are distinguished; 3) science based; and 4) information intensive, a technological trajectory added in a later contribution (Pavitt et al., 1989).

One of the first taxonomic exercises drawing on Pavitt's work and applied to services is that proposed in various contributions by Soete and Miozzo (Soete and Miozzo 1989; Miozzo and Soete 2001). These authors attempt to break down Pavitt's category of supplier dominated firms, which initially included the whole of the services sector (in the 1984 article). In Pavitt and colleagues' 1989 contribution, the parts of the sector were moved to the information intensive category. Soete and Miozzo reposition the various service industries on the basis of an enlarged version of the set of main 'ingredients' employed by Pavitt. 
A large chunk of service sectors remains pure supplier dominated, including public and social services such as health, education, public administration, personal services (hotels and restaurants, domestic, repair) and distributive services (which includes the macro retail compartment). The characteristics of these sectors, which are widely heterogeneous in terms of firm size, mainly rely on technology adopted from the manufacturing sector. Soete and Miozzo reprise the 1989 version of Pavitt's taxonomy and introduce the scale/network intensive category, which includes sectors depending on large physical networks and information networks, respectively transport services and financial services. Both these branches are composed of large firms and are not simple adopters of technology developed elsewhere (embodied in capital equipment or in a large ICT infrastructure). Rather, they contribute to defining and specifying the types of innovation introduced by using the network infrastructures adopted.

Overall, Soete and Miozzo's main ingredients, for instance, 'type of user', are primarily impressionistic, all the more so as the authors provide a typical top-down rather than the bottom-up exercise based on empirical evidence, as in the original Pavitt contribution. Nevertheless, their contribution stands as the first attempt to break down Pavitt's original 'supplier dominated' category, although Pavitt himself did acknowledge the increasing role of information based sectors, among which he included services.

There have been a few attempts made to provide an empirical base to the 'top-down' taxonomic exercise of Soete and Miozzo. Among these are the works by Evangelista (2000) and Evangelista and Savona (2003), which are based on the CIS data, for the case of Italy. Despite a certain number of shortcomings pointed out by Djellal and Gallouj (1999), large scale surveys such as the CIS provide a richer set of innovation indicators - not all of which are technological. Evangelista and Savona ${ }^{5}$ map the service sectors according to certain dimensions, such as intensity of innovation expenditure, type of innovation expenditure (including such items as know-how, design and training, type and intensity of innovation cooperation with clients and other agents) and, finally, the main objectives of firms'

\footnotetext{
${ }^{5}$ We refer to Evangelista (2000) and Evangelista and Savona (2003) for the methodological details of the empirical analysis carried out to identify the technological trajectories and map the service sectors.
} 
innovation strategies. A few trajectories are identified on the basis of the empirical indicators mentioned above. These are traditional technology users and the science and technology based users. Also, a new trajectory is identified that is peculiar to service activities, which is the Interactive and ICT Users. In Evangelista and Savona (2003), this typology is used to assess the impact of different innovation trajectories on the level of employment and the quality of skills.

\subsection{The Service-based (Differentiation) Approach}

As mentioned above, the service-based or differentiation approach (Gallouj 1994) includes contributions that responded to the dominant technologist (assimilation) stream of literature on innovation in services. This approach focuses on the specificities of innovation in services, in an attempt to rebalance the focus on technology and enlarge the innovation perspective to embrace non-technological aspects.

The specificity of innovation can be approached in a deductive way. The intrinsic characteristics of service outputs (immateriality, interactivity, co-production)-described in Section 2 - are all ideal-types, which are the basis of a number of hypotheses on the specificity of innovation in services. In particular, the interactive and dynamic characteristics of service outputs make the traditional analytical categories of innovation product, process, organizational innovation - inadequate and also possibly reductive - not easily separable when dealing with services. As a consequence, the very counting and assessment of innovation intensity and its economic impact become intrinsically more difficult. Similarly, the interactive nature of service production and delivery makes identification of the subjects of the innovation - the appropriation of its benefits - as well as their organizational modes more difficult.

It is also convenient - possibly simpler -- to approach service specificity in an inductive way. Empirical contributions that try to identify specific, non-traditional types of innovation have flourished, focusing on specific cases of service sectors (section 3.2.1), 
going into greater depth by providing local theories (i.e. theories adapted to specific service sectors), or reassessing existing sectoral taxonomies (Section 3.2.2).

\subsubsection{The empirical typologies}

The first generation of service-oriented contributions focused on KIBS and business services in general. For the case of consultancy, for instance, Gadrey and Gallouj (1998) renounce the traditional typology product/process, proposing one that accounts for the cognitive nature of this activity, defined as devices to treat knowledge to produce more knowledge. Gadrey and Gallouj distinguish among three forms of innovation: (i) ad-hoc innovation, which is unique solution, co-produced specifically to resolve a client's problem; (ii) new expertise-field innovation, which involves a new domain of expertise; (iii) formalization innovation, which seeks to make the output less fuzzy, through mechanisms such as the design of new methods, technical equipment use, etc. This typology is based on a series of detailed, qualitative interviews.

These first, qualitative based typological attempts were followed by more quantitative surveys aimed at measuring the intensity of the various modes of innovation identified. Whereas those surveys that Djellal and Gallouj (1999) label 'subordinate' -- carried out within the assimilation perspective, the next wave of surveys - 'autonomous' surveys emphasized service specificity.

The typological efforts were subsequently applied to analyze sectors other than KIBS and financial sectors. In particular, they focused on services with lower competence and knowledge intensity, such as transport, cleaning and personal services. In each of these domains, particular forms of innovation are identified, not necessarily related to the use of technology; these have contributed to enriching the ingredients of the service-oriented typologies of innovation.

Typological contributions also encompass innovation in complex, composite services, such as tourism. According to Caccomo and Solonadrasana (2001), (see also Sundbo et al., 
2007), tourism is composed of a series of temporal phases of goods and private services (such as transport, hotels and restaurants, leisure), and also public services (natural environments, health infrastructure, tourist information offices). The domain encompassing the interaction between public and private service innovation in composite services, such as tourism, has not been explored to date and offers a research area with rich potential.

\subsubsection{The conceptualization of innovation in specific service sectors and the improvement of sectoral taxonomies}

In addition to empirically-based typologies, a number of service-oriented contributions exist. These are more conceptual in nature, resembling 'local theories' of innovation in services, and have aimed at identifying sector-specific innovation behaviors without pretending to generalize them or to provide an all-embracing theory of innovation in services.

Analysis of innovation in the retail trade, for instance, borrows largely from management studies. Here, we highlight 'accordion theory' (Hollander 1966) and the 'theory of the retailing wheel' (McNair 1958). These contributions look at innovation in the retail trade as the evolution of shop formats (hard discount) towards more complex systems with higher service intensity. In a recent book (Gallouj 2007), these theories are reprised and assessed in terms of their ability to provide an exhaustive account of the diversity of innovation behaviors in retail trade. Gallouj argues that neither shop format theories nor technological dynamics alone are able to provide a comprehensive local theory of innovation in retailing.

Financial services received conspicuous analytical attention. Out of these contributions, a local theory of innovation in financial services has developed (Niehans 1983; Desai and Low 1987). The work by Desai and Low, for instance, is interestingly based on a service characteristics approach. The financial product is decomposed into a vector of characteristics such that innovation in financial sectors is seen as a process of adding new characteristics or improving existing ones. We draw on these early attempts (Section 4), introducing the interrelations among different types of characteristics and vectors of 
internal and external competences, in order to provide a conceptual framework able to account for innovation in both goods and services.

We have seen that innovation typologies - classified amongst the technologist approaches tend to associate firm and sector behaviors with technology-based trajectories. These typologies represent a substantial step forward towards identification of the sector-specific nature of technology trajectories and innovation performance.Nevertheless, as argued in this paper, they under-estimate the variety of non-technological dimensions of innovation in services. We have progressed from Pavitt's single category of supplier dominated, through Soete and Miozzo's several (though still technology based) trajectories, to richer dimensions of innovation in services, which are both empirical and conceptual.

A new functional approach to the definition of products allows us simultaneously to overcome the technology-bias of innovation theories, to disentangle the one-to-one relation between sector of activity and taxonomy category, and to provide a conceptual framework for both goods and services. Drawing on a functional decomposition of services, within the characteristics-based definition of the service and the vector of competences mobilized to produce them, Gallouj (2002) and Djellal (2002) identify new modes and types of innovation and the dynamic evolution of different trajectories.

\section{The integrative (synthesis) approach: the characteristics-based definition of product and its potential for innovation theory}

This section is devoted to the so-called integrative approach to innovation in services, which, in our view, is the most promising in terms of theoretical advancement. As mentioned above, we believe that such a synthesis is becoming more necessary as the boundaries between goods and services become more blurred. On the one hand, the immaterial components of goods are becoming important, while on the other the standardization of certain service activities is becoming easier and cheaper. This process of convergence is a symptom of the advanced economies moving from service economies to 
economies based on service relationships or new modes of coordination amongst agents (De Bandt and Gadrey, 1994).

The contributions in this area redefine the product in such a way that it offers a relatively solid framework to generalize a theory of innovation for material and immaterial product. The first contributions, which are integrative in nature, but not within the Lancasterian characteristics-based approach described in the next section, include those by Belleflamme et al. (1986) and Barcet et al. (1987). These works share a functional approach to economic activity, according to which a need, that is, a function, can be satisfied through the consumption of a good or a service, or both. From this perspective, the distinction between a material good and a service becomes redundant; rather these authors consider the act of consuming as the act of satisfying a need. The concept of need, along with the use of the characteristics-based approach to define the product, has been reprised and extensively used by Valente (1999) and Ciarli and Valente (2005) within an evolutionary formalized framework to model technical change, industrial dynamics and economic growth. In the same vein, Windrum and Birchenhall $(1998,2005)$ adopt the characteristics based approach within an evolutionary framework.

In the pursuit of our main objective in this paper, in the next section, we revert to some work done by one of the authors, which can be seen as an attempt to provide a unifying, integrative approach to the definition of products and a richer typology of innovation in both goods and services.

\subsection{An integrative approach to innovation based on the characteristics-based definition of} products

The Lancasterian (and post-Lancasterian) characteristic-based approach to the definition of product, in our view, represents a powerful theoretical tool to operationalize such a synthesis and account for a much richer set of innovation modes. Gallouj and Weinstein (1997) (see also Gallouj 2002) reprise the Lancasterian characteristic-based representation of product (Lancaster, 1966) proposed by Saviotti and Metcalfe (1984). They consider a 
product (either a good or a service) to be represented by a set of vectors of characteristics and competences that are linked.

Figure 1 illustrates the characteristics-based representation of a product. Vector [Y] represents the service characteristics, the final users' value. Vector [T] represents the technical characteristics of the product, material or immaterial. Underlying vector $[\mathrm{T}]$ is the process (technological and non-technological) employed to produce vector [Y]. Vectors [C] and $\left[C^{\prime}\right]$ indicate the competence sets of the supplier and the customer-user, respectively. The vector product $[\mathrm{C}]\left[\mathrm{C}^{\prime}\right]$ is the supply-delivery interface between producers and users.

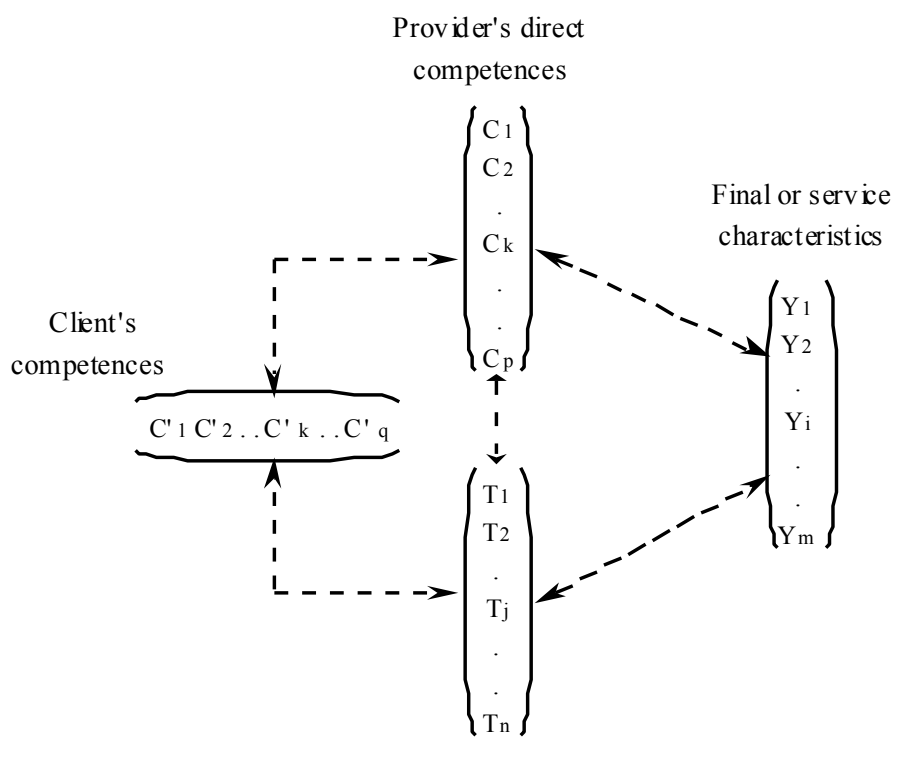

Material and immaterial technical characteris tics

Figure 1 The characteristics-based representation of the product.

Source: Gallouj and Weinstein 1997

The delivery of a service could therefore be defined as the simultaneous employment (and relationship) of technical characteristics (material and immaterial) and competences (internal and external) ultimately used to produce the service (or final) characteristics. This representation encompasses a number of particular cases: for instance, a pure service case is 
given by the direct employment of the competences and service characteristics vectors [C]$[\mathrm{Y}]$; the relation $[\mathrm{T}]-[\mathrm{Y}]$ represents a pure material good; the link between $[\mathrm{C}]-[\mathrm{T}]-[\mathrm{Y}]$ identifies a self-service relationship.

Innovation can be defined accordingly as the changes affecting one or more elements of one or more vectors of characteristics (both technical and service) or of competences. These changes are intended to be defined by one or more basic mechanisms: evolution or variation, exit or entry of one or more elements; and association, dissociation or formatting of one or more elements. These can be planned or intentional, perhaps as the outcome of research and development $(R \& D)$ activities, or unintentional, that is, emerging from an inertial learning process by the agents involved.

Innovation, therefore, is defined not as a result, but as a process. Rather than identifying 'types' of innovation, this framework allows us to identify and to embrace different 'models' of innovation, as a result of the dynamics of their characteristics. Some of these are described below.

- Radical innovation is defined by the creation of a new set of vectors of competences, technical and service characteristics $\left\{\left[\mathrm{C}^{*}\right],\left[\mathrm{C}^{*}\right],\left[\mathrm{T}^{*}\right],\left[\mathrm{Y}^{*}\right]\right\}$. A stricter definition of radical innovation implies a new set of vectors of competences and technical characteristics, which provide the same vector of service (or user) characteristics $\left\{\left[\mathrm{C}^{\prime *}\right]\right.$, $\left.\left[\mathrm{C}^{*}\right],\left[\mathrm{T}^{*}\right],[\mathrm{Y}]\right\}$. In this respect, the use of an electric car substituting horse-transports represents a radical innovation, despite the vector of service characteristics (transport, speed, safety, comfort) being the same, though to a different degree.

- Improvement innovation occurs when the set of vectors of characteristics remains unchanged, but the quality value of their single elements increases. Such a process is facilitated in turn either by improvements in certain elements of the competence vectors [C]or [C'] or in the technical characteristics [T]. This model reproduces the process of 'competence enhancing' a la Tushman and Anderson (1986), which draws on the learning effects intrinsic to any of the activities considered. 
- Incremental innovation is defined according to the original meaning of the increments added to one or more elements of the vectors. The main aim of this category is to overcome the intrinsic ambiguity carried by the traditional notion of incremental innovation. This traditional notion is often represented in the innovation literature as a sort of residual, once it is established that the change does not represent a radical innovation. In the present context, incremental innovation occurs when a new characteristic is added, eliminated or substituted, but leaving the whole set of vectors $\left\{\left[\mathrm{C}^{\prime}\right],[\mathrm{C}],[\mathrm{T}],[\mathrm{Y}]\right\}$ unchanged.

- $\quad$ Ad hoc innovation is typical of (but not exclusive to) high knowledge intensity activities. These typically result in a new solution to a client problem, whether juridical, strategic, organizational or technical in nature. From the point of view of the supplier, producing an ad hoc innovation means contributing to the whole set of competences, and the knowledge underlying them, in such a way that a new competence is produced, codified and formalized in order to be transferred to the user and eventually reproduced. Ad hoc innovation implies a significant change in the vector of competences [C], and also and mostly in the immaterial elements of the technical characteristics vector.. It should be noted that the degree of codification and formalization a posteriori required to allow reproducibility of the new solution based on an 'ad hoc' innovation, distinguishes this type of innovation from the one off solutions typical of many service transactions.

- Recombination innovation implies a different association or dissociation of service and technical characteristics. In this context, incremental innovation can be considered as a particular case of recombination innovation that involves adding characteristics typical of pre-existing products. There are two more cases that fall within the category of recombination innovation in the domain of services, which are highlighted by Bressand and Nicolaïdis (1988). The first implies the creation of a new product as a combination (or association) of characteristics of one or more products. The second consists of the creation of a new product by means of fragmentation (or dissociation) of the characteristics of a preexisting product. 
- Formalization innovation occurs when one or more characteristics are formatted or standardized. In the case of services, this mode of innovation adds a certain degree of materiality to the service provided. This can be accomplished by using a new technological system (traditionally seen as a process innovation) or by modifying the intangible production and delivery process and its organization.

\subsection{Some recent attempts to operationalise the characteristics based-approach}

Some recent attempts to operationalize and/or extend the characteristics based approach to the analysis of innovation in services can be found in the contributions by De Vries (2006) and Windrum and Garçia Goni (2008).

The former introduces vectors of characteristics representing the customer's own technology and other providers' technologies and competencies in order to take account of the contribution of network organizations to the output. Both extensions encompass modes of innovation such as the distributed innovation process (Miles, 2000) and the role of the client in co-production. These extensions have the potential to be used to add to the conceptualization of the vertical relationships among client and provider and networkshaped organizations.

By developing an evolutionary model of health services innovation, Windrum and GarçiaGoni (2008) introduce the characteristics of the public policy maker, in order to encompass innovation modes, irrespective of the ownership (public or private) of the provider enterprise. The policy maker, therefore, is one of the agents interacting in the model, which is endowed with preferences and competences and affects the complex interactions behind the innovation process, which in turn becomes the outcome of a balance of power and potentially conflicting preferences. In the context of the present discussion, what is interesting about Windrum and Garçia-Goni's (2008) contribution is that the authors draw on the characteristics-based approach to address the problem of innovation measurement in services. In their model, all five of Schumpeter's dimensions of innovation - 
organizational, product, process, market and input - as well as the difference between incremental and radical innovation, are re-elaborated in terms of changes in characteristics.

Similarly, and with the aim of making the integrative framework more operational in the case of some complex service organizations and types of provision, Djellal and Gallouj $(2005,2008 \mathrm{a})$ draw on the work of Hill $(1977,1999)$ and Gadrey $(1996,2000)$, and combine it with the characteristic-based approach (Gallouj and Weinstein 1997; Gallouj, 2002). The cases they describe refer to 'assembled' service (e.g. a hospital), which is a complex activity that can be defined as follows (Table 1):

1. The single constituent services ( $\mathrm{Si}$,) composed by basic functions or groups of operations that add up to the assembled service.

2. These functions are associated with specific targets: material objects $(\mathrm{M})$, information (I), knowledge $(\mathrm{K})$ or individuals $(\mathrm{R})$. These different groups of operations are material, informational, methodological and relational operations.

2. The service characteristics obtained or desired (Y).

3. The competences of the service providers (C). 
Table 1: A framework for analyzing the output of an assembled service (Djellal and Gallouj, 2005)

\begin{tabular}{|c|c|c|c|c|c|c|}
\hline $\begin{array}{c}\text { Constitu } \\
\text { ent }\end{array}$ & $\begin{array}{l}\text { Competenc } \\
\text { es }\end{array}$ & \multicolumn{4}{|c|}{$\begin{array}{l}\text { Service medium, corresponding operations or } \\
\text { functions and associated technologies }\end{array}$} & \multirow{2}{*}{$\begin{array}{c}\text { ('External } \\
\text { ') use, } \\
\text { final or } \\
\text { service } \\
\text { characteris } \\
\text { tics or } \\
\text { functions } \\
\text { Y } \\
\text { Service } \\
\text { functions } \\
\text { and } \\
\text { characteris } \\
\text { tics (+ } \\
\text { correspon } \\
\text { ding } \\
\text { disciplines } \\
\text { ) }\end{array}$} \\
\hline $\mathrm{S}_{\mathrm{i}}$ & $\begin{array}{c}\text { C } \\
\text { Competenc } \\
\text { es in (the } \\
\text { use of) } \\
\text { technologie } \\
\text { s or } \\
\text { competenc } \\
\text { es directly } \\
\text { mobilized }\end{array}$ & $\begin{array}{c}\text { M } \\
\text { 'Material' } \\
\text { operations } \\
(+ \\
\text { correspond } \\
\text { ing } \\
\text { sciences } \\
\text { and } \\
\text { technologie } \\
\text { s) }\end{array}$ & $\begin{array}{l}\text { I } \\
\text { 'Informatio } \\
\text { nal' } \\
\text { operations } \\
\quad(+ \\
\text { correspond } \\
\text { ing } \\
\text { sciences } \\
\text { and } \\
\text { technologie } \\
\text { s) }\end{array}$ & \begin{tabular}{l}
\multicolumn{1}{c}{ K } \\
'Methodolog \\
ical' \\
operations \\
$\quad(+$ \\
correspondin \\
g sciences \\
$\quad$ and \\
technologies)
\end{tabular} & \begin{tabular}{l}
\multicolumn{1}{c}{$\mathrm{R}$} \\
Contractual \\
or \\
relational \\
service \\
operations \\
\multicolumn{1}{c}{$\quad(+$} \\
correspond \\
$\quad$ ing \\
\multicolumn{1}{c}{ sciences } \\
$\quad$ and \\
technologie \\
\multicolumn{1}{c}{ s) }
\end{tabular} & \\
\hline $\begin{array}{l}\mathrm{S}_{1}(\mathrm{si} 1, \\
\mathrm{si} 2, \ldots \\
\text { sij,... } \\
\text { sim) }\end{array}$ & & & & & & \\
\hline $\mathrm{S}_{2}$ & & & & & & \\
\hline $\mathrm{S}_{3}$ & & & & & & \\
\hline$\ldots$ & & & & & & \\
\hline $\mathrm{S}_{\mathrm{i}}$ & & & & & & \\
\hline$\ldots$ & & & & & & \\
\hline$S_{n}$ & & & & & & \\
\hline
\end{tabular}

The product can therefore be represented as the association of various constituent services (Si). Each of theses services can itself be seen as the implementation of competences related to the combinations of basic operations carried out on objects, information, knowledge or individuals, in order to produce changes. Dynamic implementation of this model provides the basis for developing a systematic framework for analyzing the principles driving innovation in this type of activity. Innovation not only covers the whole of the area marked out by our analytical grid, but also can change the size of that area, 
depending on the type of organizing principle introduced. The extensive and regressive principles involve, respectively, adding or eliminating a new constituent service (action in the rows of the table). The intensive principle involves extending or improving a given cognitive or technological component of the product (action in the columns of the table), while the combinatory principle, which is more frequently encountered, links the other principles and produces innovation by combining (associating and/or separating) different constituent services and/or different technologies. These different modes of innovation are described in detail in Djellal and Gallouj (2005 and 2008a).

\section{Concluding remarks}

The paper provides a review of the literature on innovation in services, reclassifying the various contributions according to their assimilation, demarcation or integrative nature with respect to the more consolidated literature focused on technological innovation in the manufacturing sector.

First, in Section 2 we reviewed the historical debate on the productive/unproductive nature

of services, claiming that this debate is rooted in both the evolving theory of value and the ill-definition of service output and its consequent mis-measurement of services productivity and value added. There is currently no consensus on these issues, which consequently have influenced the development of innovation theory and the way this has been extended to the service domain.

The assimilation or technologist approaches remain dominant. Whether they are confined to examining the impacts of technological innovation on service firms and industries or whether they advance more developed theoretical constructions (taxonomies of innovation trajectories, reverse cycle theory), these studies overlook the non-technological aspects of innovation and therefore underestimate the innovative intensity of service activities. 
A flourishing literature emphasizes the service specificities of product and innovation modes by focusing on sector specific cases. In Section 3, we briefly reviewed the most significant of these, though they are still not able to encompass innovation in a general framework.

In this respect, the approach based on (service, technical and process) characteristics and competences that we have developed in this paper (Section 4), and which draws on the work of Lancaster (1966) and Saviotti and Metcalfe (1984), belongs to the integrative stream of literature. We argue that this is the most promising and all-encompassing approach to a more balanced theory of innovation, able to overcome the materiality and technology bias which has characterized the more than century long debate on services. 


\section{References}

Abernathy W.J., Utterback J.M. (1975) A Dynamic Model of Process and Product Innovation. Omega 3 (6): 639-656.

Abernathy W.J., Utterback J.M. (1978) Patterns of industrial innovation. Technology Review 80: 41-47.

Aglietta M, Brender A (1984) Les métamorphoses de la société salariale. Calman-Lévy, Paris.

Appelbaum E, Schettkat R (2001) Are prices unimportant? The changing structure of the industrialised economies. In: T ten Raa and R Schettkat (eds), The growth of service industries. The paradox of exploding costs and persistent demand. Edward Elgar, Cheltenham, pp 121-131.

Attali J, (1981) Les trois mondes. Fayard, Paris.

Bacon R, Eltis W (1978) Britain's economic problem: Too few producers. Macmillan, London.

Barcet A, Bonamy J Mayère A (1987) Modernisation et innovation dans les services aux entreprises. Commissariat Général du Plan.

Barras R (1986) Towards a theory of innovation in services. Research Policy, 15: 161-173.

Barras R (1990) Interactive innovation in financial and business services: The vanguard of the service revolution. Research Policy, 19: 215-237.

Baumol, WJ (1967) Macroeconomics of unbalanced growth: The anatomy of an urban crisis. American Economic Review, 57: 415-426.

Baumol, WJ (2001) Paradox of the services: Exploding costs, persistent demand. In: T ten Raa and R Schettkat (eds), The growth of service industries. The paradox of exploding costs and persistent demand. Edward Elgar Cheltenham, pp 3-28.

Baumol, WJ (2002) Services as leaders and the jeader of the services. In: J Gadrey and F Gallouj (eds), Productivity, innovation and knowledge in services. Edward Elgar, Cheltenham, pp 147-163.

Baumol WJ, Bowen W (1966) Performing arts: The economic dilemma. Twentieth Century Fund, New York. 
Baumol WJ, Blackman S, Wolff E (1985) Unbalanced growth revisited: Asymptotic stagnancy and new evidence. American Economic Review 75: 806-816.

Baumol WJ, Blackman S, Wolff E (1989) Productivity and American leadership. MIT Press, Cambridge, MA.

Bell D (1973) The coming of post-industrial society. A venture in social forecasting. Basic Books, New York.

Belleflamme C, Houard J, Michaux B, (1986) Innovation and research and development process analysis in service activities. IRES, EEC-FAST report, August.

Bresand A, Nicolaïdis K (1988) Les services au cœur de l'économie relationnelle, Revue d'Economie Industrielle 43: 141-163.

Browning H, Singelmann J (1978) The transformation of the U.S. labour force: The interaction of industries and occupation. Politics and Society 3-4: 481-509.

Caccomo J-L, Solonandrasana B (2001) L'innovation dans l'industrie touristique. L'Harmattan, Collection Tourisme et Sociétés, Paris.

Cainelli G, Evangelista R, Savona M (2006) Innovation and economic performance in services. A firm-level analysis. Cambridge Journal of Economics, 30: 435-458.

Ciarli T, Valente M (2005) Firms' interaction and industrial development: A simulation model. In: E Giuliani, R Rabellotti and MP Van Dijk (eds) Clusters facing competition: The importance of external linkages. Ashgate, Aldershot, pp 259-290.

Clark C (1940) The conditions of economic progress. Macmillan, London.

Cohen S, Zysman J (1987) Manufacturing matters. Basic Books, New York.

Daveri F (2002) The new economy in Europe, 1992-2001. Oxford Review of Economic Policy, 18(3): 345-362.

De Bandt J, Gadrey J (eds) (1994) Relations de service, marchés des services. CNRS Editions, Paris.

Delaunay JC, Gadrey J (1992) Services in economic thought - Three centuries of debate. Kluwer Academic Publishers, Dordrecht.

Desai M, Low W (1987) Measuring the opportunity for product innovation. In: M De Cecco (ed) Changing money: Financial innovation in developed countries. Basil Blackwell, Oxford, pp 112-140. 
De Vries E (2006) Innovation in services in networks of organizations and in the distribution of services. Research Policy, 35(7): 1037-1051.

Djellal F (2000) The rise of information technologies in non informational services. Vierteljahrshefte zur wirtschaftsforschung, 69(4), Special issue.

Djellal F (2002) Innovation trajectories in the cleaning industry. New Technology and Employment, 17(2): 119-131.

Djellal F, Gallouj F (1999) Services and the search for relevant innovation indicators: A review of national and international surveys. Science and Public Policy, 26(4): 218-232.

Djellal F, Francoz D, Gallouj C, Gallouj F, Jacquin Y (2003) Revising the definition of research and development in the light of the specificities of services. Science and Public Policy, 30(6): 415-430.

Djellal F, Gallouj F (2005) Mapping innovation dynamics in hospitals. Research Policy, 34: 817-835.

Djellal F, Gallouj F (2008a) A model for analysing the innovation dynamic in services: The case of assembled services. International Journal of Services Technology and Management (forthcoming).

Djellal, F, Gallouj, F (2008b) Measuring and improving productivity in services: issues, strategies and challenges. Edward Elgar, London (forthcoming).

Evangelista R (2000) Sectoral patterns of technological change in services. Economics of innovation and new technology, 9: 183-221.

Evangelista R, Savona M (2003) Innovation, employment and skills in services: firm and sectoral evidence. Structural Change and Economic Dynamics, 14: 449-474.

Fisher AGB (1935) The clash of progress and security. Macmillan, London.

Fourastié J (1949) Le grand espoir du XX siècle. Presse Universitaire de France, Paris.

Fuchs, V (1968) The service economy. National Bureau of Economic Research, New York.

Fuchs V (1977) The service industries and U.S. economic growth since World War II. NBER Working Paper Series 211 (November).

Gadrey J (1996) Services: la productivité en question. Desclée de Brouwer, Paris.

Gadrey J (2000) The characterization of goods and services: An alternative approach. The review of income and wealth. Series 46, $\mathrm{n}^{\circ} 3$, September, 369-387. 
Gadrey J, Gallouj F (1998) The provider-customer interface in business and professional services. The Service Industries Journal, 18(2): 1-15.

Gallouj C (2007) Innover dans la grande distribution. De Boeck, Bruxelles.

Gallouj C, Gallouj F (1996) L'innovation dans les services. Edition Economica, Paris.

Gallouj F (1994) Economie de l'innovation dans les services, Editions L'Harmattan, Logiques économiques, Paris.

Gallouj F (1998) Innovating in reverse: Services and the reverse product cycle. European Journal of Innovation Management, 1(3): 123-138.

Gallouj F (2002) Innovation in the service economy: The new wealth of nations. Edward Elgar, Cheltenham.

Gallouj F, Weinstein O (1997) Innovation in services. Research Policy 2: 537-556.

Gershuny J (1978) After industrial society? The emerging self-service economy. MacMillan, London.

Griliches, Z (ed) (1971) Price indexes and quality change. Harvard University Press, Cambridge, MA.

Griliches, Z (ed) (1992) Output measurement in the service sector. University of Chicago Press, Chicago, Ill.

Hill TP (1977) On goods and services. The Review of Income and Wealth, 4(23): 315-338.

Hill TP (1999) Tangibles, intangibles and services: A new taxonomy for the classification of output. Canadian Journal of Economics, 32(2): 426-444.

Hollander SC (1966) Notes on the retail accordion. Journal of Retailing, 42(2): 24-34.

Howells J. (2006) Where to From Here for Services Innovation? a Paper presented at the Knowledge Intensive Services Activities (KISA) Conference, Sydney, 22 March.

Kline S, Rosenberg N (1986) An overview of innovation. In: R Landau and N Rosenberg (eds), The positive sum strategy: Harnessing technology for economic growth. National Academy Press, Washington DC, pp 275-305.

Kox H, Rubalcaba L (2007) Analysing the contribution of business services to European economic growth. Bruges European Economic Research Papers, 9, January.

Kutscher R, Mark, J (1983) The service-producing sector: Some common perceptions reviewed. Monthly Labour Review, April: 21-24. 
Kuznets S (1957) Quantitative aspects of the economic growth of nations, II: Industrial distribution of national product and labour force. Economic Development and Cultural Change Supplement, July.

Kuznets S (1966) Modern economic growth, rate, structure and spread. Yale University Press, New Haven, CT.

Lancaster KJ (1966) A new approach to consumer theory. Journal of Political Economy 14: 133-156.

Lorenzi J-H, Pastré O, Tolédano J (1980) La crise du XXe siècle. Economica, Paris.

McNair MP (1958) Significant trends and developments in the post war period. In: AB Smith (ed) Competitive distribution in a free high level economy and its implication for the university. University of Pittsburgh Press, Philadelphia, PA.

Miles I (2000) Service innovation: Coming of age in the knowledge based economy. International Journal of Innovation Management (4): 371-389.

Miles I (2002) Service innovation: Towards a tertiarisation of innovation studies. In: J Gadrey and F Gallouj (eds) Productivity, innovation and knowledge in services. Edward Elgar, Cheltenham, pp 164-196.

Miles I (2005) Innovation in services. In: J Fagerberg, D Mowery and R Nelson (eds) The Oxford Handbook of Innovation, Oxford University Press, Oxford.

Miozzo M, Soete L (2001) Internationalisation of services: A technological perspective. Technological Forecasting and Social Change, 67(2/3):159-185.

Moulton BR (1991) A Bayesian approach to regression selection and estimation, with application to a price index for radio services. Journal of Econometrics, 49: 169-193.

Moulton BR (2001) The expanding role of Hedonic methods in the official statistics of the United States. Bureau of Economic Analysis, U.S. Department of Commerce, June.

Niehans J (1983). Financial innovation, multinational banking, and monetary policy. Journal of Banking and Finance, 7: 537-51.

OECD (2000a) A new economy? The role of innovation and information technology in recent OECD economic growth. OECD, Paris.

OECD (2000b) A New Economy? The Changing Role of Innovation and Information Technology in Growth. Paris, OECD.

OECD (2000c) The service economy. OECD, Paris. 
OECD (2001) The new economy: Beyond the hype. The OECD growth project. OECD, Paris.

Pavitt K (1984) Sectoral patterns of technical change: Towards a taxonomy and a theory. Research Policy 13: 343-374.

Pavitt K, Robson M, Townsend J (1989) Technological accumulation, diversification and organisation in UK companies. Management Science 35: 81-99.

Peneder M (2001) Structural change, development and growth. Paper presented at the The Future of Innovation Studies Conference. Eindhoven University, Eindhoven, Netherlands.

Peneder M, Kaniovsky S, Dachs B (2003) What follows tertiarisation? Structural change and the role of knowledge-based services. The Service Industry Journal 23: 47-66.

Petit P (1986) Slow growth and the service economy. Pinter, London.

Saviotti PP, Metcalfe JS (1984) A theoretical approach to the construction of technological output indicators. Research Policy 13: 141-151.

Savona M (2004) Structural change and macro-economic performance. The structural bonus hypothesis for services. Paper presented at the XIV International Conference of RESER, IUT Castres and Toulouse, France, 23-25 September.

Savona M, Lorentz A (2005) Demand and technology contribution to structural change and tertiarisation. An input-output structural decomposition analysis. LEM Working Paper Series, 2005/25, http:/www.lem.sssup.it/WPLem/files/2005-25.pdf.

Schettkat R, Yocarini L (2006) The shift to services employment: A review of the literature. Structural Change and Economic Dynamics, 17: 127-147.

Smith A (1960) [1776] The Wealth of Nations. The Modern Library, Random House, New York.

Soete L, Miozzo M (1989) Trade and development in services: A technological perspective. Maastricht Economic Research Institute on Innovation and Technology (MERIT) Working paper 89-031.

Sundbo J (1998) The organisation of innovation in services. Roskilde University Press, Roskilde, Denmark.

Sundbo J, Gallouj F (1999) Innovation as a loosely coupled system in services. International Journal of Services Technology and Management, 1(1):15-36. 
Sundbo J, Orfila-Sintes F, Soerensen F (2007) The innovative behaviour of tourism firms. Comparative studies of Denmark and Spain, Research Policy 36(1): 88-106.

Ten Raa T, Schettkat R (eds) (2001) The growth of service industries. The paradox of exploding costs and persistent demand. Edward Elgar, Cheltenham.

Tether, B, (2005), Do Services Innovate (Differently)?: Insights from the European Innobarometer Survey, Industry and Innovation, 2005, 12: 153-184

Tushman ML, Anderson P (1986) Technological discontinuities and organizational environments. Administrative Science Quarterly, 31: 439-465.

Valente M (1999) Evolutionary economics and computer simulation. A model for the evolution of markets Vol. 1: Consumer Behaviour and Technological Complexity in the Evolution of Markets. DPhil dissertation, University of Aalborg, Denmark.

Windrum P, Birchenhall C (1998) Is life cycle theory a special case?: Dominant designs and the emergence of market niches through co-evolutionary learning. Structural Change and Economic Dynamics, 9: 109-134.

Windrum P, Birchenhall C (2005) Structural change in the presence of network externalities: A co-evolutionary model of technological successions, Journal of Evolutionary Economics, 15(2): 123-148.

Windrum P, Garçia-Goni M (2008) A neo-Schumpeterian model of health services innovation, Research Policy (forthcoming). 